\title{
PENGARUH PENGGUNAAN MEDIA DALAM MENURUNKAN KANDUNGAN AMONIA PADA LIMBAH CAIR RUMAH POTONG AYAM (RPA) DENGAN SISTEM BIOFILTER ANAEROB
}

\author{
Oleh : Muhammad Al Kholif
}

\begin{abstract}
Abstrak :
Karakteristik limbah cair yang dihasilkan dari kegiatan industri RPA sangat bervariasi. kandungan bahan organik tinggi disertai konsentrasi bahan padat dan lemak yang relatif tinggi mengakibatkan terjadinya pencemaran lingkungan. Limbah rumah potong ayam umumnya mengandung zat pencemar seperti BOD, COD dan Amonia ynag tinggi. Kandungan ammonia pada limbah rumah potong ayam umumnya melebihi baku mutu yang sudah ditetapkan. Tujuannya adalah mengetahui kemampuan biofilter anaerobik dalam menurunkan kandungan amonia pada air limbah RPA. Sampel diambil langsung pada bak pencucian ayam setelah bulu tercabut. Media yang digunakan dalam penelitian ini yaitu media bioball dan media pecahan batu kali untuk menurunkan beban pencemar amonia pada air limbah RPA dengan sistem biofilter anaerob tercelup aliran upflow. Reaktor yang digunakan dalam percobaan ini adalah terdiri dari 4 reaktor dengan ukuran berbeda-beda. Pada reaktor pertama dan kedua memiliki volume $0,04 \mathrm{~m}^{3}$ dan pada reaktor ke tiga dan ke empat bervolume $0,018 \mathrm{~m}^{3}$. Efisiensi penyisihan kandungan amonia disimpulkan bahwa penerapan media bioball lebih besar menyisihkan kandungan amoni dari pada media pecahan batu kali yaitu lebih dari $90 \%$.
\end{abstract}

Kata Kunci : ammonia; Limbah Cair RPA; Media Bioball.

\section{PENDAHULUAN}

Kegiatan RPA akan menghasilkan limbah dengan kandungan bahan organik tinggi disertai konsentrasi bahan padat dan lemak yang relatif tinggi. Menurut Kusnoputranto (1995) limbah ini akan berdampak pada kualitas fisik air yaitu warna dan $\mathrm{pH}$ disamping itu total padatan terlarut, padatan tersuspensi, kandungan lemak, $\mathrm{BOD}_{5}$, ammonium, nitrogen, fosfor akan mengalami peningkatan. Limbah terbesar berasal dari darah dan isi perut (Tjiptadi 1990) sedangkan darah berdampak pada peningkatan nilai BOD dan padatan tersuspensi. Disamping itu isi perut (rumen) dan usus akan meningkatkan jumlah padatan. Pencucian karkas juga meningkatkan nilai BOD. Sedangkan Bewick (1980) menyatakan bahwa limbah ternak merupakan sumber pencemaran bagi air yang mempunyai kandungan BOD tinggi dan kandungan oksigen yang terlarut di dalam air relatif sedikit. Untuk menangani limbah yang dihasilkan oleh kegiatan RPA, maka ada tiga kegiatan yang perlu dilakukan yaitu identifikasi limbah, karakterisasi dan pengolahan limbah (Ross et al., 1992). Hal ini harus dilakukan agar dapat ditentukan suatu bentuk penanganan limbah RPA yang efektif.

Industri RPA menghasilkan limbah baik dalam proses itu sendiri serta dalam mencuci peralatan dan fasilitas, hal ini ditandai dengan tingginya konsentrasi zat organik dan padatan tersuspensi (Amorim et al., 2007). Jumlah dan karakteristik air limbah di industri RPA ini sangat bervariasi tergantung pada proses industri dan air yang digunakan tiap melakukan aktivitas pemotongan ayam (Del Nery et al., 2001a). Air limbah RPA yang berupa isi rumen atau isi lambung, darah afkiran, daging atau lemak, dan air cuciannya, dapat bertindak sebagai media pertumbuhan dan perkembangan mikroba sehingga limbah tersebut mudah mengalami pembusukan. Dampak negatif dari industri ini yaitu menghasilkan limbah berbentuk padat dan cair. Industri RPA sebagian besar menghasilkan air limbah yang mengandung bahan organik biodegradable dalam jumlah tinggi, dalam hal ini materi koloid seperti lemak, protein dan selulosa (C.E.T. Caixeta et al., 2002; D. Masse, dan L. Masse 2001; L.A. Nunez, dan B. Martinez 1999). 
Kandungan limbah cair RPA diantaranya adalah limbah kimia-fisik dan mikrobiologi. Mikroba yang terkandung dalam limbah cair RPA diantaranya adalah Bacillus subtilis, Bacillus thuringiensis, dan Lysinibacillus fusiformis (Tarntip dan Thungkao, 2011).

Sumber pencemar yang lain seperti kandungan BOD (Biological Oxygen Demand), COD (Chemical Oxygen Demand) dan amonia dalam air buangan industri RPA juga sangat tinggi yaitu di atas ambang batas dari kandungan BOD, COD dan amonia yang sudah ditetapkan. Hasil sampling awal didapatkan kandungan BOD sebesar $402 \mathrm{mg} / \mathrm{L}$, COD sebesar $656 \mathrm{mg} / \mathrm{L}$ dan amonia sebesar $75,57 \mathrm{mg} / \mathrm{L}$. Kegiatan RPA akan menghasilkan limbah dengan kandungan bahan organik tinggi disertai konsentrasi bahan padat dan lemak yang relatif tinggi. Untuk mencegah hal itu maka diperlukan cara agar komposisi padatan organik tersuspensi dapat dikurangi (Laksono dan Kirana 2010).

Jenis limbah utama yang dihasilkan dari sebuah industri RPA pada umumnya terdiri dari darah, bulu, jeroan (sisa-sisa usus dan potongan kloaka), tulang dan ayam mati. Dari hasil pengukuran diketahui bahwa limbah berupa darah yang dihasilkan adalah sekitar 3,5\%, limbah usus $5 \%$, serta limbah ayam mati sekitar $0,5 \%$ dari jumlah ayam yang dipotong dalam satu hari (Voslarova et al., 2007; Bolu dan Adakeja, 2008). Sebagian besar dari jenis limbah yang meliputi lemak, usus, kepala, tulang sisa dari proses pengolahan daging tanpa tulang (boneless), kulit, hati, ampela dan ceker/kaki ayam masih mempunyai nilai jual yang tinggi dan dibutuhkan oleh pengguna tertentu. Untuk menangani limbah yang dihasilkan oleh kegiatan RPA, maka ada tiga kegiatan yang perlu dilakukan yaitu identifikasi limbah, karakterisasi dan pengolahan limbah (Ross et al., 1992). Tujuan dalam percobaan ini adalah mendapatkan suatu bentuk penanganan limbah RPA yang efektif dengan menerapkan sistem pengolahan biofilter anaerob. Masalah yang dituangkan adalah berapa besar efisiensi penurunan kandungan amonia pada air buangan industri RPA jika dilakukan pengolahan dengan sistem biofilter anaerobik tercelup. Secara keseluruhan penyisihan kandungan beban pencemar pada limbah RPA seperti kandungan amonia lebih dari $90 \%$ setelah dilakukan pengolahan dengan sistem biofiltef anaerob tercelup.

\section{METODE PENELITIAN Sampel Penelitian}

Sampel diambil langsung pada industri RPA di daerah Waru Sidoarjo. Sampel yang digunakan dalam percobaan ini merupakan limbah cair RPA setelah proses pencabutan bulu selesai. Limbah cair RPA yang diambil sebagai sampel percobaan merupakan hasil pencucian ke 2 (dua) sehingga kandungan darahnya sudah berkurang. Pada pencucian pertama tidak diambil sebagai sampel percobaan karena air limbah RPA nya tergolong limbah panas dan bulu ayam belum tercabut artinya ayam masih dalam proses perendaman dengan air panas. Dari hasil analisis sebelum dilakukan pengolahan didapatkan bahwa limbah RPA mengandung zat pencemar ammonia sebesar $75 \mathrm{mg} / \mathrm{L}$.

\section{Peralatan dan Bahan Percobaan}

Dalam penelitian ini alat dan bahan yang akan digunakan adalah :

a. Alat

Reaktor biofilter anaerobik dari akrilik dengan ketebalan $5 \mathrm{~mm}$, tandon air dari plastik, pipa PVC dan sambungannya, pompa, penyangga, media bioball diameter $3 \mathrm{~cm}$, pipet dan jirigen.

Reaktor 1 dan 2 bervolume $0,04 \mathrm{~m}^{3}$ dan reaktor 3 dan 4 bervolume $0,018 \mathrm{~m}^{3}$. Rekator 1 dan 2 diisi dengan media bioball sedangkan reaktor 3 dan 4 di isi dengan media pecahan batu kali.

b. Bahan

Limbah cair RPA yang diambil langsung pada drum pencucian ayam setelah proses pencabutan bulu.

Gambar potongan memanjang model reaktor Biofilter anaerob tercelup dan peralatan pelengkap yang digunakan dalam penelitian ini adalah seperti Gambar 1. 


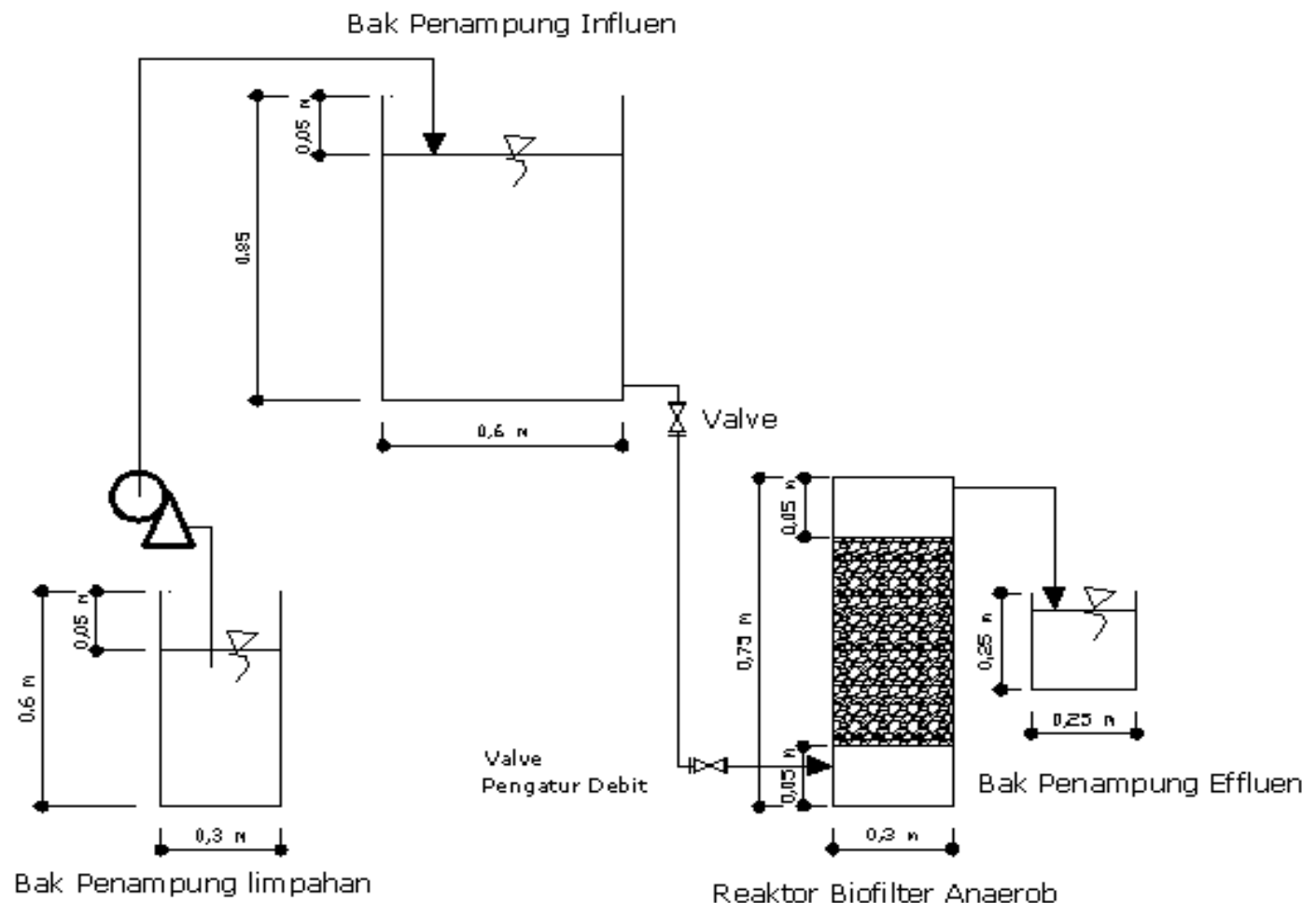

\section{Tahap Pengumpulan Data}

Pengumpulan data dilakukan dengam menggunakan metode observasi antara lain :

a. Analisis kualitas air limbah awal, meliputi parameter $\mathrm{BOD}_{5}$ terlarut, $\mathrm{COD}$ dan amonia.

b. Prosedur pengoperasian reaktor biofilter adalah sebagai berikut :

1) Mengatur konsentrasi influen air limbah yang masuk ke dalam reaktor dengan menggunakan valve sesuai dengan debit yang diinginkan yaitu sebesar $0,045 \mathrm{~m}^{3} /$ hari atau $31,25 \mathrm{ml} / \mathrm{menit}$. Media biofilter yang yang digunakan dalam penelitian ini adalah media bioball dan media pecahan batu kali berdiameter $3 \mathrm{~cm}$.

2) Effluen dari biofilter diambil dan dianalisis sesuai dengan parameter yang diukur secara berkala. Pengukuran parameter amonia dilakukan dengan analisis sebelum dan sesudah pengolahan.

c. Prosedur analisis amonia dilakukan setelah didapatkan hasil dari nilai kalibrasi antara reagen dan sampel. Dari hasil pengamatan di laboratorium didaptkan hasil dari kalibrasi antara reagen dan sampel limbah RPA dengan menggunakan spektrofotometri pada panjang gelombang 410 $\mu$. Hasil dari kalibrasi amonia ini kemudian dijadikan sebagai dasar untuk menghitung kandungan amonia yang didapat dari hasil pengukuran di spektrofotometri.

\section{Metode Analisis Data}

Hasil pengamatan akan dianalisis secara grafik dan dijelaskan untuk mengetahui seberapa besar efisiensi removal air limbah RPA dari masing-masing media. Metode grafik dijadikan sebagai acuan dalam melihat penurunan dari parameter yang diamati.

\section{HASIL DAN PEMBAHASAN}

Pengolahan secara aerobik dianggap kurang cocok untuk air limbah RPA atau RPH karena konsumsi energi yang tinggi untuk aerasi, produksi lumpur yang jumlah besar, dan keterbatasan mentransfer oksigen (Gavala et al, 1996;. Rajeshwari et al, 2000;. Speece, 1996). Oleh karena itu, proses biologis anaerobik lebih cocok dan telah digunakan untuk mengolah air limbah RPA ini dengan konsentrasi influen yang tinggi. Reaktor anaerobik tingkat tinggi telah dijadikan sebagai 
alternatif yang baik dan efektif karena banyak keuntungan seperti biaya awal dan operasional yang rendah, kebutuhan ruang yang lebih kecil, tingginya efisiensi penyisihan kandungan bahan organik dan produksi lumpur yang rendah, selain itu proses ini menghasilkan energi bersih melalui produksi biogas yang dapat dimanfaatkan. Beberapa teknologi pengolahan dapat diterapkan dalam mengolah limbah RPA ini seperti contac anaerob (AC), upflow anaerobic sludge blanket (UASB), proses anaerobic filter (AF), dan urutan reactor batch anaerob (ASBR) (US-EPA, 2002; Johns, 1995). Kinerja IPAL biofilter menunjukan hasil yang sangat baik, dengan kualitas olahan yang sangat baik.

\section{Kandungan Amonia}

Keberadaan senyawa amonia dapat menyebabkan kondisi toksik bagi kehidupan perairan. Kadar amonia bebas dalam air meningkat sejalan dengan meningkatnya $\mathrm{pH}$ dan suhu. Kehidupan air terpengaruh oleh amonia pada konsentrasi $1 \mathrm{mg} / \mathrm{L}$ dan dapat menyebabkan mati karena dapat mengurangi konsentrasi oksigen dalam air (Widayat dkk, 2010).

Kandungan amonia yang tinggi dan bahan organik yang rendah merupakan karakteristik utama dari limbah RPA secara anaerobik. Limbah RPA yang mengandung senyawa amonia yang tinggi dengan bahan organik yang rendah dapat dioleh dengan menerapkan sistem teknologi sequencing batch reaktor (SBR) (Shengquan et al, 2008; Keller et al, 1997; Pochana, et al, 1999; Subramaniam, et al, 1994). Konsentrasi bahan organik rendah, oksigen terlarut cukup dan waktu tinggal lumpur yang lama memungkinkan proses nitrifikasi dan denitrifikasi berada pada kondisi yang stabil (De Nardi, et al 2011).

Secara kimia, keberadaan amonia di dalam perairan dapat berupa amonia terlarut $\left(\mathrm{NH}_{3}\right)$ dan ion amonium $\left(\mathrm{NH}_{4}{ }^{+}\right)$. amonia bebas $\left(\mathrm{NH}_{3}\right)$ yang tidak terionisasi bersifat toksik bagi organisme akuatik. Persentase amonia bebas meningkat dengan meningkatnya $\mathrm{pH}$ dan suhu perairan. Menurut Effendi (2003), toksisitas amonia terhadap organisme akuatik dipengaruhi oleh pH, kadar oksigen terlarut, dan suhu. Pada $\mathrm{pH}$ rendah amonia akan bersifat racun jika jumlahnya banyak, sedangkan pada kondisi $\mathrm{pH}$ tinggi amonia akan bersifat racun meskipun kadarnya rendah. Penurunan kadar oksigen terlarut akan meningkatkan toksisitas amonia dalam perairan.

\section{Efisiensi Penurunan Kandungan Amonia pada Media Bioball}

Media sebagai tempat tumbuh dan berkembangbiaknya mikroorganisme pengurai limbah dapat bersumber dari bioball, pecahan batu kali, kayu, plastik dan lain-lain. Umumnya media yang digunakan berbahan keras dan mudah untuk diperoleh. Media bioball yang digunakan dalam percobaan ini bermedia $3 \mathrm{~cm}$ yang memiliki ruas-ruas sebagai tempat tumbuh dan berkembangbiaknya mikroorganisme. Efisiensi penurunan kandungan ammonia yang terjadi pada media bioball seperti yang terlihat pada gambar 1 . 


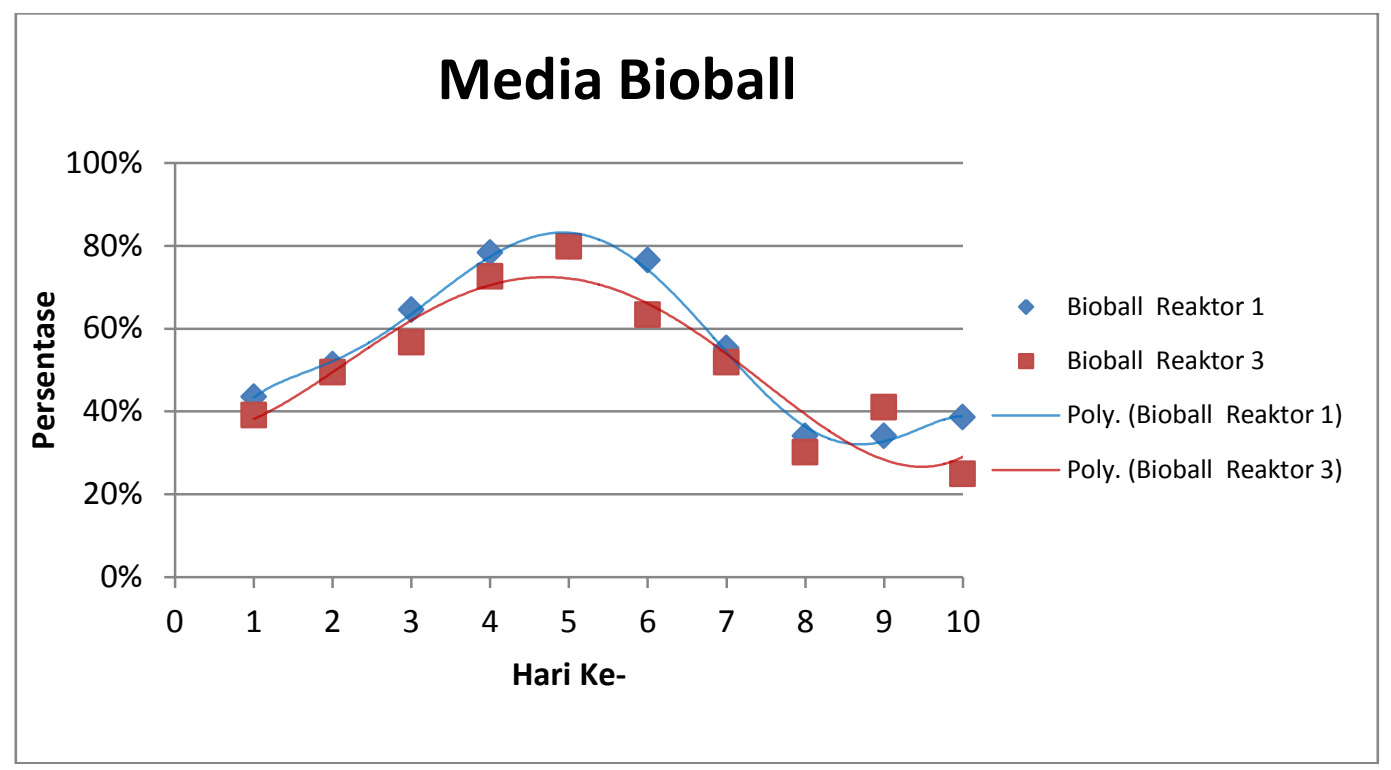

Gambar 2. Efisiensi Penurunan Kandungan Amonia pada Reaktor Media Bioball

Efisiensi penurunan kandungan ammonia pada reaktor bermedia bioball menunjukan penurunan yang cukup signifikan. Penurunan kandungan ammonia tertinggi yantu sebesar $80 \%$ terjadi pada pengamatan hari ke-5 untuk reaktor 1 dan 3 . Hal ini menunjukan bahwa kinerja mikroorganisme dalam mengurai zat pencemar ammonia paling optimal menyisihkan sebesar $80 \%$.

\section{Efisiensi Penurunan Kandungan Amonia pada Media Pecahan Batu Kali}

Media pecahan batu kali merupakan salah satu media yang sering digunakan oleh para peneliti lingkungan sebagai tempat tumbuh dan berkembangbiaknya mikroorganisme penguraizat pencemar. Keberadaannya yang mudah ditemukan membuat peneliti tidak kesulitan dalam mencari media tersebut. Dalam percobaan ini media pecahan batu kali juga digunakan untuk dijadikan sebagai tempat berkembangbiaknya beberapa mikroorganisme pengurai limbah.

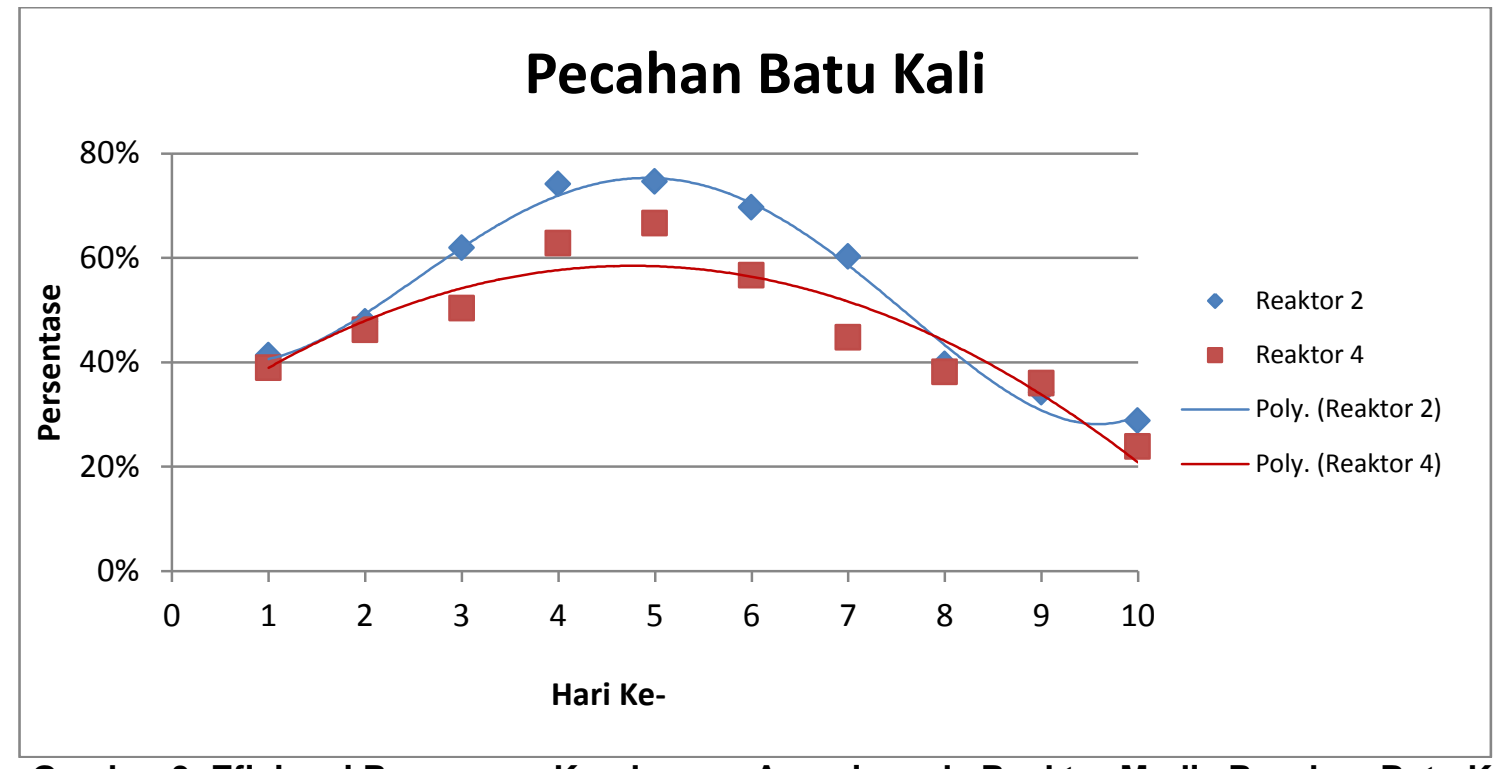

Gambar 3. Efisiensi Penurunan Kandungan Amonia pada Reaktor Media Pecahan Batu Kali 
Pada media pecahan batu kali ini juga terjadi penurunan ammonia. Hal ini menunjukan bahwa kinerja mikroorganisme dalam menyisihkan kandungan ammonia cukup maksimal. Penyisihan kandungan ammonia tertinggi terjadi pada pengamatan hari 5 yaitu sebesar $75 \%$ pada reaktor 2 dan $67 \%$ pada reaktor 4 .

\section{KESIMPULAN}

Hasil analisis dapat disimpulkan bahwa penyisihan beban pencemar limbah cair RPA dari masing-masing media secara umum terjadi penurunan atau penyisihan yang signifikan. Hal ini terbukti dengan angka penyisihan kandungan beban pencemar yang mencapai angka lebih dari 80 Angka penyisihan tertinggi terjadi pada media bioball dengan menyisihkan kandungan beban pencemar ammonia sebesar $80 \%$.

\section{Ucapan Terima Kasih}

Penelitian ini telah mendapatkan dukungan dari dekan, ketua jurusan Teknik Lingkungan, dan kepala laboratorium Teknik Lingkungan Universitas PGRI Adi Buana Surabaya. Selain itu disampaikan ucapan terimakasih kepada Irfan Setya Budi yang telah banyak membantu dalam penelitian ini.

\section{Daftar Pustaka}

Amorim A.K.B, de Nardi I.R, Del Nery V. Water Conservation and Effluent Minimization : Case Study of a poultry Slaughterhouse. Resources, Conservation and Recycling 51 (2007) 93100.

Bewick. M.W.M. 1980. Handbook of Organic Waste Convertion Litton Educational Publishing, Inc. New York.

Bolu, S.A. dan A. Adakeja. 2008. Effects of poultry offal meal and soyabean meal mixtures on the performance and carcass quality of broiler chicks. African J. Food, Agric. Nutr. and Develop. 8(4): $441-550$.

De Nardi,I.R., V. Del Nery, A.K.B. Amorim, N.G. dos Santos, F. Chimenes, Performances of SBR, Chemical-DAF and UV Disinfection for Poultry Slaughterhouse Wastewater Reclamation, Desalination, 269 (2011) 184-189.

Del Nery V, Damianovic MHZ, Barros FG. The Use of an Upflow Anaerobic Sludge Blanket Reactor in the Treatment of Poultry Slaughterhouse Wastewater. Water Sci Technol 2001a; 44 (4) : $83-89$.

Effendi, Hefni. 2003. Talaah Kualitas Air : Bagi Pengelolaan Sumber Daya Alam dan Lingkungan Perairan. Yogyakarta : Penerbit Kanisius.

Gavala, H. N., Skiadas, I. V., Nikolaos, A. B., Lyberatos, G. (1996) Anaerobic digestion of agricultural industries wastewaters. Water Science and Technology, 34 (11), 67-75.

Johns, M. R. (1995). Developments in Wastewater Treatment in the Meat Processing Industry: A review. Bioresource Technology, 54, 203-216.

Keller, J., Subramaniam, K., J. Gösswein, P.F. Greenfield, 1997. Nutrient Removal from Industrial Wastewater Using Single Tank Sequencing Batch Reactors, Water Sci. Technol. 35 (6) (1997) 137-144.

Kusnoputranto, H. 1995. Limbah Industri dan B-3 Dampaknya terhadap Kualitas Lingkungan dan Upaya Pengelolaannya. Pusat Penelitian Lingkungan Hidup Univ. Mulawarman.

Laksono, M.S. dan Kariana, M. 2010. Peningkatan Produktivitas dan Kinerja Lingkungan dengan Pendekatan Green Productivity Pada Rumah Pemotongan Ayam. Jurnal Fakultas Teknologi Industri, Institut Teknologi Sepuluh Nopember Surabaya

Masse, D.I., Masse, L. 2001. The Effect of Temperature on Slaughterhouse Wastewater Treatment in Anaerobic Sequencing Batch Reactors, Bioresour. Technol. 76 (2001) 91-98.

Nunez L.A., B. Martinez. Anaerobic Treatment of Slaughterhouse Wastewater in an Expanded Granular Sludge Bed (EGSB) Reactor, Water Sci. Technol. 40 (1999) 99 - 106. 
Pochana, K., Keller, J. 1999. Study of Factors Affecting Simultaneous Nitrification and Denitrification (SND), Water Sci. Technol. 39 (6) (1999) 61-68.

Rajeshwari, K. V., Balakrishnan, M., Kansal, A., Lata, K. and Kishore, V.V.N. (2000) State-of-the-art of anaerobic digestion technology for industrial wastewater treatment. Renewable and Sustainable Energy Reviews, 4 (2), 135-156.

Ross, A.D.; R.A.Lawrie; J.P. Keneally dan M.S. Whatmuff. 1992. Risk Characterisation Management of Sewage Sludge on Agricultural Land-Implications for the Environmental and Foodchain. Aust. Vet. Journal 69 (8): 177- 181.

Shengquan Y, G. Siyuan, W. Hui. High Effective to Remove Nitrogen Process in Abattoir Wastewater Treatment, Desalination 222 (2008) 146-150.

Speece, R. E. (1996). Anaerobic Biotechnology for Industrial Wastewaters, Archae Press, Nashville, TN.

Subramaniam, K., P.F. Greenfield, K.M. Ho, M.R. Johns, J. Keller, 1994. Efficient Biological Nutrient Removal in High Strength Wastewater Using Combined Anaerobic Sequencing Batch Reactor Treatment, Water Sci. Technol. 30 (6) (1994) 315-321.

Tarntip.R., S. Thungkao. 2011. Isolation of Proteolytic, Lipolytic, and Bioemulsifying Bacteria for Improvement of the Aerobic Treatment of Poultry Processing Wastewater. Afr. J. Microbiol. Rsc 5 (2) : 30-35

Tjiptadi, W. 1990. Pengendalian Limbah Pertanian. Makalah pada Pendidikan Kependudukan dan Lingkungan Hidup Bagi Wydiasnara Sespa, Sepadya, Sepala dan Sespa Antar Departemen. Jakarta.

U.S. Environmental Protection Agency. (2002). Onsite Wastewater Treatment Systems Manual. EPA/625/R-00/008. U.S. Environmental Protection Agency, Washington, D.C.

Voslarova, E., B. Janackova, L. Rubesova, A. Kozak, I. Bedanova, L. Steinhauser., V. Vecerek. 2007. Mortality Rates in Poultry Species and Categories during Transport for Slaughter. ACTA VET. BRNO 2007, 76: 101-108.

Widayat Wahyu, Suprihatin dan Arie Herlambang. 2010. Penyisihan Amoniak dalam Upaya Meningkatkan Kualitas Air Baku PDAM-IPA Bojang Renged dengan Proses Biofiltrasi Menggunakan Media Plastik Tipe Sarang Tawon. Jurnal Teknologi Lingkungan Volume VI (1) : $64-76$ 